\title{
LITERÁRNÍ PŘÍNOS ŽIDOVSKÉ MENŠINY V MULTIKULTURNÍM PROSTŘEDÍ BUKOVINY
}

\author{
RADEK MALÝ
}

Malý, Radek: Literary Contribution of the Jewish Minority in the Multicultural Environment of Bukovina, 2019, Vol. 1, Issue 2, pp. 38 - 44. DOI: 10.17846/CEV.2019.01.2.38-44.

ABSTRACT: The paper focuses on topos of the region of Bukovina. It is a historical region in Eastern Europe, which is currently divided between Romania and Ukraine. Its historical capital Chernivtsi is a city in southwestern Ukraine, situated on the upper course of the river Prut in the northern part of Bukovina. Ukrainians, Romanians, Poles, Ruthenians, Jews, Roma from Bukovina wrote poetry. Very famous are authors like Paul Celan and Rose Ausländer.

KEYWORDS: Bukovina. Paul Celan. Middle Europe. Ukraine. Jewish Literature. Multiculturalism.

Stř̌ední Evropa je pojem, který, jak známo, lze definovat spíše sociálně-kulturně než geopoliticky. Jedná se v jistém smyslu o koncept harmonického soužití, který v praxi po delší dobu nikdy nefungoval. $V$ dějinách Evropy však nalézáme region, jehož genius loci byl ve své době natolik výjimečný, že představoval jakýsi reálný model střední Evropy v malém. Jedná se o východoevropskou Bukovinu - kraj, v němž žilo vedle sebe v míru a ve vzájemném obohacování několik národů, z nichž žádný neměl výraznou většinu, a tudíž nemohl dokazovat svou kulturní převahu. Pro Bukovinu (německy Buchenland) vynalezli její novodobí objevitelé řadu metafor: „tavicí kotlík národů“, „model sjednocené Evropy“ či „židovské Eldorado starého Rakouska“; pro její hlavní město Černovice pak např́klad „poetická Atlantida“ nebo „evropská Alexandrie“.

Bukovina sousedící s historickými územími Haličí, Besarábií, Moldávií a Sedmihradskem je region rozdělený dnes mezi Ukrajinu a Rumunsko; lesnaté a hornaté území na úpatí Karpat o rozloze něco přes $10000 \mathrm{~km}^{2}$, které v roce 1775 ćítalo pouhých 75000 obyvatel. Jeho význam a neobvyklost tak spočívá především v pluralitě místních kultur. Vzešli odtud či s tímto krajem své dílo spojili významní spisovatelé mnoha evropských národů: klasici ukrajinského písemnictví Jurij Fedkovič, Ivan Franko, Osyp Makovej či Olha Kobyljanská, rumunský pozdně romantický básník Mihai Eminescu či polský básník Aleksander Morgenbesser, dále řada autorů židovského původu píśících v jidiš jako např. Elieser Steinbarg, Itzig Manger či poslední černovický židovský spisovatel Josef Burg (1912 - 2009). Roku 1880 se zde rovněž narodil český spisovatel Otakar Theer.

Nejvýrazněji však evropskou literaturu obohatili odtud pocházející spisovatelé píśící německy, vesměs židovského původu, a jména jako Karl Emil Franzos, Rose Ausländerová, Paul Celan či Gregor von Rezorri se stala nedílnou součástí světového písemnictví. Do dějin moderní německé literatury pak se zpožděním pronikla řada dalších jmen básníků a básnírek, z nichž jmenujme ty nejdůležitější: Moses Rosenkranz, Alfred Gong, Alfred Kittner, Immanuel Weißglas, Selma Meerbaum-Eisingerová či Georg Drozdowski.

Klíč k mnohonárodnostní identitě Bukoviny poskytuje historický vývoj oblasti. Ve starověku toto území obývali Dákové. Ve středověku zde vládli nejprve Avaři, potom se zde však usídlili Slované a Bukovina se stala součástí Haličsko-volyňského knížectví. V 10. - 11. století území patřilo ke Kyjevské Rusi. Od 14. století byla Bukovina součástí Moldavského knížectví, avšak území si nárokovalo i Polsko. Od roku 1514 až do osmnáctého století se Bukovina ocitla pod nadvládou Osmanské říše. Po ústupu Turků z Balkánu obsadila toto území rakouská vojska a roku 1775 se Bukovina stává součástí rakouské monarchie spadající pod Halič - a až tehdy, na popud císaře 
Josefa II., na území výrazněji vstupuje německý živel a s ním související nedobrovolná germanizace všech zde žijících etnik. Nejvýznamnější v historii regionu je bezesporu období v letech 1849 - 1918, kdy byla Bukovina samostatnou korunní zemí habsburské monarchie. V této době obývalo území kolem půl milionu lidí nejrůznějších národností.

Po první světové válce připadlo území Rumunskému království. Němčina zde přesto vedle rumunštiny platila jako úřední jazyk až do roku 1924 a kulturní vzmach oblasti, jehož podněty přicházely od židovského obyvatelstva, neustával. Atmosféru pokojného soužití však narušil nástup druhé světové války - v červnu roku 1940 severní část území anektoval Sovětský svaz, byly zahájeny deportace Židů a německy mluvící obyvatelstvo začalo Bukovinu hromadně opouštět. V červnu roku 1941 obsadila celé území fašistická rumunská armáda, podporovaná jednotkami SS. Následovaly masivní deportace židovského obyvatelstva do koncentračních táborů v Transnistrii za řekou Bug a v hlavním městě bylo zř́zeno ghetto. Černovice byly Rudou armádou znovu dobyty v březnu roku 1944. Ze 75000 transportovaných Židů se jich do Černovic vrátilo 9000 . Současný podíl židovského obyvatelstva v Černovicích (cca 250000 obyvatel) čítá pouhých $0,6 \%$.

Bukovina byla roku 1947 rozdělena: severní část včetně Černovic se stala součástí SSSR, dnes představuje tzv. Černovickou oblast v rámci samostatné Ukrajiny. Jižní Bukovina s hlavním městem Suceava je součástí Rumunska. V někdejší hlavní černovické synagoze je od padesátých let zrrízeno městské kino. Arménský kostel, postavený podle návrhu českého architekta Josefa Hlávky, slouží jako varhanní sál černovické filharmonie.

K tomuto přehledu historických milníků je třeba připočíst jimi podmíněnou etnickou rozmanitost oblasti v období, kdy patřila habsburské monarchii. Zpočátku byli nejpočetněji zastoupeni Rumuni, kteří oblast osídlili z Karpatského oblouku. Nositele slovanského živlu představovali Ukrajinci osidlující oblast ze severu, kteří koncem 19. století získali v obyvatelstvu převahu. K nim je možno připočítat někdy jako samostatně vnímané východoslovanské etnikum Huculů. Třetím nejpočetněji zastoupeným etnikem na přelomu 18. a 19. století byli Židé, jejichž podíl představoval $13 \%$, v hlavním městě však dokonce téměř polovinu všech obyvatel. Právě židovské obyvatelstvo představované především intelektuály se zásadním zpưsobem podílelo na kulturním rozkvětu oblasti. Skutečnost, že židovské obyvatelstvo mluvilo převážně německy a cítilo svou př́slušnost $\mathrm{k}$ německé kultuře, způsobuje jejich časté automatické přiřazování pod skupinu německého obyvatelstva - etničtí Němci však představovali samostatnou poměrně početnou skupinu (asi $9 \%$ ). V celé oblasti žili rovněž Poláci, s nimiž cítili př́íslušnost v Bukovině žijící Arméni. Samostatně je třeba uvést etnikum Lipovanů, kteří tvořili uzavřené komuny, dále pak Madary, Slováky, Čechy a Romy.

Specifické postavení v rámci Bukoviny zaujímá její hlavní město Černovice, rozkládající se na několika pahorcích na břehu řeky Prut. Jednalo se o kulturní i duchovní centrum celé oblasti. Asimilovaní Židé - zejména obchodníci, bankéři, právníci, lékaři, učitelé a úředníci - hlásící se $\mathrm{k}$ německé národnosti tvořili plné tři čtvrtiny německého obyvatelstva a vnášeli do města řadu podnětů: roku 1808 bylo otevřeno první německé gymnázium, od roku 1839 působila ve městě divadelní scéna a budova divadla z roku 1905 byla využívána jak Němci, tak i Rumuny. Samostatné židovské divadlo v Černovicích bylo zřízeno Sověty v roce 1940.

Rokem 1875 se datuje založení černovické Univerzity Franze Josefa (dnes Národní univerzita Jurije Fedkkoviče), pojícího prvku celého regionu. Na této univerzitě byly např. jako první otevřeny katedry ukrajinštiny a rumunštiny. Univerzita od roku 1950 sídlí v nápadném komplexu budov, které v letech 1867 - 1874 projektoval a vystavěl rovněž Josef Hlávka, původně jako sídlo bukovinského metropolity. Jím užitý retrospektivně-eklektický styl organicky propojuje prvky románské, byzantské, maurské a gotické s elementy bukovinské lidové architektury a upozorňuje tak na pestrost kulturních vlivů v tomto městě, kde stojí chrámy čtyř různých náboženských vyznání. 
(Mimochodem: do prvního ročníku na univerzitě nastoupili i čtyři čeští studenti a svého času měly Černovice přímé vlakové spojení s Prahou). Univerzitní budova byla roku 2011 zapsána na seznam světového kulturního dědictví UNESCO.

Etnická různorodost města by sama o sobě nebyla $\mathrm{z}$ dnešního pohledu tak fascinující, kdyby nebyla podpořena ideou sounáležitosti a mírového soužití. Nositeli těchto integračních snah byli opět především, ale nejenom Židé. Od sedmdesátých let devatenáctého století zažil nebývalý rozkvět rovněž denní tisk - tři nezávislé deníky a několik časopisů bylo vydáváno židovskými nakladateli. Není divu, že v této době městu sami jeho obyvatelé s oblibou přezdívali „malá Vídeň“.

$\mathrm{Na}$ druhém břehu řeky se nachází městečko Sadagora (ukrajinsky Sadhora), dnes součást Černovic. Sadagora se od poloviny devatenáctého století stala centrem chasidismu, hnutí židovské lidové zbožnosti s rysy mysticismu, a desetitisíce zbožných Židů sem proudily z celé východní Evropy. Od roku 1842 zde působil legendární zázračný rabbi Israel Friedmann, zvaný Ruzyner, zakladatel několika chasidských dynastií. O významu Sadagory pro Černovice svědčí například poněkud skurilní název jedné básně nejslavnějšího místního rodáka Paula Celana ze sbírky Růže nikoho: Gaunerská a grázlovská písnička zpívaná Paris emprès pontoise Paulem Celanem z Černovic u Sadagory (Eine Gauner- und Ganovenweise gesungen zu Paris emprès pontoise von Paul Celan aus Czernowitz bei Sadagora). ${ }^{1}$

O mnohém $\mathrm{z}$ historie Černovic vypovídají př́iběhy místních pomníků. Před zdejším divadlem stál za dob rakouského mocnářství pomník Friedricha Schillera, v rumunském období pomník básníka Mihaie Eminesca a dnes se na témže místě nachází pomník Olhy Kobyljanské. Poslední dva jmenovaní v Černovicích působili a psali zde své texty - mimo jiné také v němčině. Friedrich Schiller měl v Černovicích řadu oddaných ctitelů a jeho díla se pravidelně objevovala na repertoáru místního divadla.

Bukovinský „kulturní fenomén“ má několik kořenů. Především se o něj zasloužily unikátní historicko-politické a sociální okolnosti - vedle mnohonárodnostního složení a zázemí, které poskytovala habsburská monarchie, zmiňme zejména integrační roli němčiny, která umožňovala různým bukovinským etnikům kontakt se soudobou evropskou kulturou, ale zároveň byla nástrojem běžné komunikace. Tehdy v Evropě běžná národní hnutí zde byla v důsledku víceméně rovnoprávného postavení a rozložení všech etnik silně oslabená. Židovské etnikum se úspěšně asimilovalo a vnášelo do celého regionu kosmopolitní tendence.

Samožrejmá byla znalost několika jazyků - jsou známy př́klady, kdy spisovatelé vnášejí nejen lexikální, ale i např. syntaktické prvky jiného jazyka do svého literárního stylu, a zároveň téměř každý bukovinský autor psal svá díla v několika jazycích. Dosud ještě málo prozkoumaná je masivní překladatelská činnost, jíž se téměř všichni bukovinští autoři se samozřejmostí věnovali. Bukovina představovala více než literární topos; jednalo se o kulturní fenomén založený na úsilí zprostředkovat porozumění mezi zde žijícími národy, který se ovšem projevoval i samozřejmou recepcí a dalším rozvíjením literárních tradic a motivů jiných evropských kultur.

Německy psaná literatura vzniklá na území Bukoviny vznikla v okrajové části habsburské monarchie, svého vrcholu dosáhla $\mathrm{v}$ době, kdy už představovala ostrov v cizojazyčném území a na závěr byla téměř umlčena nacistickou zvůlí, když byli její čelní představitelé bud' zavražděni, nebo vyštváni do exilu. Právě tyto okolnosti z ní činí utopickou kulturní krajinu, „střední Evropu v malém“, která více než ve skutečnosti existovala odjakživa v představách a textech místních literátů. $\mathrm{V}$ tomto černovickém mýtu se fantastično prolíná s všedností a osudovost nabývá anekdotických rysů, jak dokládá následující citát z textu německého žurnalisty Georga Heinzena: „Černovice, na pưl cesty mezi Kyjevem a Bukureští, Krakovem a Oděsou, byly tajným hlavním městem Evropy,

\footnotetext{
K pochopení této básně je třeba vědět, že Sadagora nebyla jen čtvrtí zbožných Židů, ale také čtvrtí zlodějů
} a povalečů. 
ve kterém řeznické dcerky prozpěvovaly koloratury a drožkaři se přeli o Karla Krause. Kde se chodníky zametaly kyticemi růží a kde bylo více knihkupectví než pekáren. Černovice, to byl neustávající rozhovor kultur, který každé ráno vymyslel novou estetickou teorii, aby ji večer zavrhnul. Psi zde nosili jména olympských bohů a kuřata do zemè škrábala Hölderlinovy verše. Černovice, to byl zábavní parníček, kterýs ukrajinskou posádkou, německými důstojníky a židovskými pasažéry pod rakouskou vlajkou křzzoval mezi východem a západem" (Heinzen 1991, 18).

V německy psané literatuře z Bukoviny lze rozlišit dva proudy: literatura tzv. provinční, regionálního charakteru a významu, a literatura, kterou lze směle řadit do kontextu soudobé literatury rakousko-německé. Tu jako vůbec první v devatenáctém století zastupuje především Karl Emil Franzos, prozaik a publicista, který v Černovicích strávil školní léta a multikulturní atmosféra města silně ovlivnila jeho pozdějš́ literární tvorbu.

Až po první světové válce, kdy Bukovina připadla Rumunsku a němčina přestala být úředním jazykem, vstupují na černovickou literární scénu v nebývalém počtu mladí německy píšící básníci a básnírky původem v židovských asimilovaných rodinách. Navazujíce na nejlepší tradice německé literatury a (často nevědomě) židovské kultury obohacují nejednou svou poetiku rumunským a ukrajinským folklórem. Zapůsobily zde podobné sociálně-kulturní mechanismy jako v meziválečné Praze - Židé, za dob monarchie chráněni císařem, se ocitají v sociální, jazykové a náboženské izolaci; v období permanentní nejistoty. Přímo i nepřímo na ně byl vyvíjen nátlak v oblasti politické a hospodářské. Výsledkem bylo jejich upnutí se k oblasti kultury a intenzita literárního projevu.

Na rozdíl od pražských německy píšících Židů, jejichž díla mívala rozmáchlý epický charakter, ocitli se černovičtí Židé v situaci, kdy „přežili svou vlastní dobu“ a cítili přicházející zánik. Upnuli se proto k poezii v její klasické formě směřující jednak ke zmizelému světu habsburské monarchie, jednak $\mathrm{k}$ utopii - $\mathrm{k}$ vysněnému romantizujícímu světu harmonie, které se v realitě, v domovině, kde se sami stali cizinci, hrubě nedostávalo. Poezie se stala nástrojem stabilizace a překonání společenských rozporů. Tato básnická generace, jejíž vrcholnou tvorbu lze vymezit přibližně roky 1930 - 1940, se ve své poezii zaměřuje především na krajinu a žánrové výjevy z prŕrody. Nápadná je protimodernistická orientace, odkaz na tradici, která byla jinde překonána.

Proti tomuto proudu se pokusila vymezit mladší generace bukovinských literátů, kteří byli během první světové války poznamenáni zkušeností exilu. Pokoušejí se do bukovinské literatury vnést nové avantgardní impulsy - např. na stránkách ve své době významného expresionistického časopisu Der Nerv (byl založen roku 1919 básníkem a publicistou Albertem Maurüberem), který se inspiroval jak v Berlíně (časopisem Aktion Franze Pfemferta), tak ve Vídni (časopisem Die Fackel Karla Krause). Avšak i tito autoři záhy zjištují, že v situaci, kdy je samotný jazyk cizím elementem, nelze oslovovat čtenáře literárními experimenty, a upínají se opět k tradičním výrazovým formám. Toto formálně tradiční básnické vidění světa, někdy vědomě, někdy nevědomě epigonského charakteru, je však natolik obohaceno specifickou exotikou místních poměrů, že se tím spíše stává v rámci německé literární historie unikátním. Ani v této podobě se však bukovinským autorům nedaři překonat hranice regionu, byt se o to organizátor černovického literárního dění a objevitel mnoha talentů, redaktor deníku Czernowitzer Morgenblatt a sám plodný básník Alfred Margul-Sperber usilovně snaží.

Světového uznání došla poezie $\mathrm{z}$ Bukoviny až po druhé světové válce, $\mathrm{v}$ díle autorů generace, jejíž literární projev formovalo období holokaustu, život v ghettu, deportace a nasazení v pracovních táborech. Holokaust ještě zmnohonásobil intenzitu prožitku a výrazu jejich tvorby. Přeživší černovičtí Židé se po válce ve velké většině rozhodli $\mathrm{k}$ - bolestnému sice, ale $\mathrm{z}$ hlediska intenzity tvorby klíčovému - životu v diaspoře. Do světové literatury pronikla výrazněji pouze dvě jména básníka Paula Celana a básnírky Rose Ausländerové. Bylo by však chybou jejich poezii vzniklou 
v exilu považovat za jediný relikt bukovinské literární tvorby. Naopak, už v jejich literárních počátcích se ukazují příčiny pozdější velikosti jejich literárního díla. Četné antologie poezie autorů tohoto regionu vycházející od osmdesátých let dvacátého století dokládají, že zájem o bukovinskou poezii stále vzrůstá.

Zajímavým fenoménem bukovinské německy psané poezie, známým i z pražské německo-židovské literatury, je shodný výskyt některých slovních spojení, metafor i celých motivů v díle mnoha autorů. Toto jejich společné sdílení někdy nabývá až rysů citátu; jsou však spíše jeho novým pojetím, samozřejmým a specifickým v dané situaci. Tak např́klad proslulou metaforu „černé mléko“ z Celanovy Todesfuge (Fugy smrti) najdeme už mnohem dřive v básních Rose Ausländerové či Alfreda Margul-Sperbera, „hrob v povětři“ ze stejné básně v textech Immanuela Weißglase či Mosese Rosenkranze - aniž by to jakkoli snižovalo uměleckou působivost Celanovy skladby. Jiným častým motivem a zároveň klíčovým slovem v bukovinské poezii je obraz studny, jejž je nutno vnímat ve zcela konkrétní i v symbolické rovině. Přirozená všednodenní kulisa je tak zároveň ženským elementem, lůnem nabízejícím očištění, ale i mystickou spojnicí s oním světem. Ne náhodou se v poválečné poezii Bukoviny objevují obrazy opuštěné či zasypané studny nebo prrímo studny slz.

Poezie bukovinských básníků a básnířek židovského původu, vznikající v druhé polovině dvacátého století v exilu, je - více či méně vědomě - marnou snahou o znovunalezení ztracené vlasti. Toto hledání nabývá řady podob: at už se jedná o nostalgické obrazy Rose Ausländerové či „topografické “ texty Alfreda Gonga, nebo jde autor - jako v prŕpadě Paula Celana - cestou záměrného umlčování se a utvrzování se v nenahraditelnosti prožité ztráty.

Stalo se téměř floskulí, že poezie bukovinských autorů tematizující pronásledování Židů a jejich masové ničení se upíná ke snaze pojmenovat nevyslovitelné veršem, často opět tradiční básnickou formou - jakoby v rozporu se známým výrokem filosofa Theodora W. Adorna, že „psát po Osvětimi básně je barbarské“. Avšak právě v tomto vědomém aktu je třeba vidět úsilí zdejších básníků a básnířek (těch v nebývalém množství a s nejvyšší intenzitou) vrátit němčině, „jazyku vrahü“ („Mördersprache“), platnost jazyka básnického a prokázat nezničitelnost básnického výrazu mateřštiny („Muttersprache“). V druhém plánu, spíše nezáměrně, pak tato snaha představuje pokus odbourat traumata spojená s holokaustem. Paradox, že tato vzkvétající kultura vznikající v němčině byla právě německým nacismem zničena, je určující pro celou poválečnou situaci bukovinských autorů.

Nastíněný rozpor se v poezii neintencionálně projevuje např. sarkastickou slovní hřričkou či groteskou (u Immanuela Weißlase nebo Alfreda Kittnera), vyvazováním slov z jejich přirozeného kontextu formou působivých, novátorských metafor (u Rose Ausländerové) a nejradikálněji systematickým zcizováním básnického jazyka prostřednictvím šifer, přetvářením tradičního básnického lexika a narušováním zažitých jazykových struktur u Paula Celana.

Ve svém proslulém proslovu u příležitosti předání Literární ceny svobodného hanzovního města Brémy roku 1958, v tzv. Řeči v Brémách, Celan jasně pojmenovává dva prostory své poezie skutečný i duchovní. Název svého ztraceného domova nevysloví, ale nalézá pro něj hojně citovaný opis: „Krajina, z níz - po jakých oklikách! ale což vưbec existují: okliky? -, ta krajina, z níž k Vám přicházím, je nejspíše většině z Vás neznámá. Je to kraj, v němž měl domov nikoli nepatrný díl oněch chasidských př́iběhü, které nám všem německy převyprávěl Martin Buber. Byl to, smím-li ještě tuto topografickou skicu doplnit o cosi, co mi z velké dálky ted' tane před očima, - byl to kraj, v němžžzili lidé a knihy" (Celan 1983, 185).

Celanova cesta k vlastnímu básnickému výrazu nebyla jednoduchá a jeho raná tvorba spadající do černovického období (do r. 1945) byla ještě v mnoha ohledech tvorbou konvenční, byt’ mnohé z budoucího naznačující. V díle Paula Celana nachází bukovinská poezie svého nejpozoruhodnějšího dědice a pokračovatele, zároveň však básníka, který jakožto jeden z pozdních 
účastníků černovické germánsko-románsko-slovansko-židovské multikulturní sounáležitosti a zároveň přímý účastník její naprosté likvidace ve svém díle sleduje radikální odklon od všech tradic, jimž zůstali bukovinští básníci věrni.

\section{SUMMARY}

Bukovina is a historic region in Eastern Europe, which is currently divided between Romania and Ukraine. Its historical capital Chernivtsi is a city in southwestern Ukraine, situated on the upper course of the river Prut in the northern part of Bukovina. Historically, as a cultural and architectural center, Chernivtsi was even called "Little Vienna," "Jerusalem upon the Prut," or the "European Alexandria“. In 1775, the northwestern part of the territory of Moldavia was annexed by the Habsburg Empire; in 1849 was raised in status and became known as a crownland of the Austrian Empire. During the 19th and early 20th century, Chernivtsi became a center of both Romanian and Ukrainian national movements. When Austria-Hungary dissolved in 1918, the city and its surrounding area became a part of the Kingdom of Romania. In Chernivtsi lived Ukrainians, Romanians, Poles, Ruthenians, Jews, Roms and Germans. Jews from Bukovina wrote poetry, which is today very famous for authors like Paul Celan and Rose Ausländer. Because of the murder of the Jews and the resettlement and expulsion of the whole ethnic groups, above all of the Germans and the Romanians, this tradition got lost after the Second World War to a great extent. Ukrainian nationality is currently the largest nationality in this area.

\section{LITERATURA}

Celan, Paul, 1983. Ansprache anläßlich der Entgegennahme des Literaturpreises der Freien Hansestadt Bremen. In: Celan, Paul: Gesammelte Werke in fünf Teilen. Sv. 3. Frankfurt am Main: Suhrkamp.

Colin, Amy - Kittner Alfred (ed.), 1994. Versunkene Dichtung der Bukowina. Eine Anthologie deutschsprachiger Lyrik. München: Wilhelm Fink.

Goltschnigg, Daniel (ed.), 1991. Die Bukowina. Studien zu einer versunkenen Literaturlandschaft. Tübingen: Francke.

Hainz, Martin A., 2005. Celan und Czernowitz - topographische Überlegungen, in: Südostdeutsche Vierteljahresblätter, Nr 1, Jg. 2005, $32-41$.

Heinzen, Georg, 1991. Czernowitz, in: Rheinischer Merkur, 1. Februar, s. 18-19.

Pospíšil, Ivo, 2006. Střední Evropa a Slované. Brno: Ústav slavistiky Filozofické fakulty Masarykovy univerzity.

Rychlo, Peter (ed.), 2006. „Czernowitz bei Sadagora“. Identitäten und kulturelles Gedächtnis im mitteleuropäischen Raum. Konstanz: Hartung-Gorre Verlag.

Werner, Klaus, 2003. Erfahrungsgeschichte und Zeugenschaft. Studien zur deutsch-jüdischen Literatur aus Galizien und der Bukowina. München: IKGS Verlag. 
Radek Malý

\section{KONTAKT}

doc. Mgr. Radek Malý, Ph.D.

Katedra žurnalistiky Institutu komunikačních studií a žurnalistiky

Fakulta sociálních věd UK v Praze

Smetanovo nábřeží 6

11001 Praha 1

Česká republika

radek.maly@fsv.cuni.cz 